\title{
A Humanização do Parto e do Nascimento no Contexto do Sus a Partir das Experiências das Usuárias
}

\author{
Pedroso, Clarissa Niederauer Leote da Silva; Sarges, Roniele Costa; Lopez, Laura \\ Cecilia \\ Universidade do Vale do Rio dos Sino - Unisinos - cclarissa.fisioterapeuta@gmail.com
}

Introdução: o parto é algo além de um fenômeno fisiológico e natural, é visto também como um evento cultural, social, afetivo, familiar e sexual. a análise biomédica é apenas uma das maneiras de entendê-lo. no final do século XIX o parto se tornou uma prática dominada pela medicina e institucionalizada nos hospitais com o intuito de tomar o controle deste evento e restringi-lo às maternidades. a gravidez e o parto têm sido vistos cada vez mais como condições médicas e que devem ser diagnosticadas e tratadas, levando ao desempoderamento da mulher, transferindo ao médico e a instituição hospitalar todo o poder sobre o corpo feminino nesta situação de vulnerabilidade, possibilitando diversas intervenções, muitas vezes desnecessárias. no Brasil vem sendo criados vários programas de atenção ao parto a fim de oferecer um cuidado humanizado do parto e nascimento, através do Sistema Único de Saúde (SUS). Apesar dos esforços para melhorar a saúde materno-infantil no país, ainda existe elevadas taxas de morbimortalidade materna e neonatal com uma rede de atenção fragilizada. por isso, foi criada pelo Ministério da Saúde, a Rede Cegonha, operacionalizada pelo SUS, para qualificar a atenção obstétrica e infantil. no estado do Rio Grande do Sul está acontecendo um processo de implementação de um centro de parto normal, preconizada pela Rede Cegonha, na instituição a qual se realizará a pesquisa. Objetivo: o presente projeto buscará analisar as experiências das mulheres em relação à assistência ao parto e nascimento numa instituição hospitalar de Porto Alegre (RS) que encontra-se em processo de humanização. Assim visa entender como se dá a assistência ao parto e nascimento na perspectiva das mulheres usuárias da maternidade, compreender as concepções a cerca da humanização do parto dessas mulheres e examinar as práticas de humanização a partir das interações delas com os profissionais da saúde. Método:Trata-se de um estudo qualitativo de abordagem etnográfica desenhado como estudo de caso, que examina o processo de humanização de um Hospital de Porto Alegre, no cenário da inserção da instituição na Estratégia Rede Cegonha do Ministério da Saúde. Resultados esperados: Espera-se que os relatos de experiências das usuárias do SUS atendidas por esta instituição estejam corroborando com a proposta de humanização do parto e nascimento que está sendo implementada dentro do hospital. Desta forma, poderá se constatar se os programas de humanização de atenção ao parto, à mulher e a criança realmente estão ocorrendo e se são devidamente efetivos.

Pedroso, Clarissa Niederauer Leote da Silva; Sarges, Roniele Costa; Lopez, Laura Cecilia. A Humanização do Parto e do Nascimento no Contexto do Sus a Partir das Experiências das Usuárias. In: Anais do Congresso Internacional de Humanidades \& Humanização em Saúde [= Blucher Medical Proceedings, num.2, vol.1]. São Paulo: Editora Blucher, 2014. ISSN 2357-7282

DOI 10.5151/medpro-cihhs-10352 